\title{
In Vitro Rumen Degradability of Tropical Legumes and Their Secondary Metabolites Depends on Inoculum Source
}

Einar Artiles Ortega ( $\square$ einarao@uclv.edu.cu )

UGent: Universiteit Gent https://orcid.org/0000-0002-0258-3049

Pedro Yoelvys de la Fé-Rodríguez

Universidad Central Marta Abreu de las Villas

Beydis Reguera-Barreto

Universidad Central Marta Abreu de las Villas

Raciel Lima-Orozco

Universidad Central Marta Abreu de las Villas

Veerle Fievez

UGent: Universiteit Gent

Research Article

Keywords: ruminal degradability, ruminal kinetics, ruminant, trypsin inhibitor

Posted Date: December 8th, 2021

DOI: https://doi.org/10.21203/rs.3.rs-1090076/v1

License: (c) (1) This work is licensed under a Creative Commons Attribution 4.0 International License. Read Full License 


\section{Abstract}

In this study, the in vitro apparent rumen degradability of organic matter (ARDOM) and plant secondary metabolites (ARDPSM) of three tropical legumes (Mucuna pruriens, Canavalia ensiformis and Leucaena leucocephala) were assessed. For this, single end-point incubations $(24 \mathrm{~h})$ as well as kinetic assessments $(0,2,4,6,8,10,12$ and $24 \mathrm{~h})$ were set up with different inocula sources, i.e. ruminal inocula from Belgian and Cuban sheep. L-mimosine, L-canavanine, Concanavaline A (Con A) and trypsin inhibitor (TI) were the plant secondary metabolites (PSM) targeted in this study. Bean and forage/bean meals of M. pruriens and $C$. ensiformis as well as their PSM were extensively degraded during $24 \mathrm{~h}$ incubation $(0.70$ and $0.78 \mathrm{~g}$ ARDOM $/ \mathrm{g}$ of organic matter (OM), respectively and $>0.80 \mathrm{~g} / \mathrm{g}$ for L-canavanine, $>0.76 \mathrm{TIU} / \mathrm{TIU}$ for TI and $>0.95 \mathrm{~g} / \mathrm{g}$ for Con A, for both legumes). Forage meal of L. leucocephala was considerably less degraded, with apparent ruminal degradabilities of 0.20 and $0.35 \mathrm{~g} \mathrm{ARDOM} / \mathrm{g}$ OM after $24 \mathrm{~h}$ incubation with Belgian or Cuban sheep inoculum, respectively. This could - at least partially - be related to L-mimosine, present in L. leucocephala, which was hardly degraded in the Belgian incubation, while a more extensive ruminal breakdown was observed under the Cuban conditions ( 0.05 to $0.78 \mathrm{~g}$ ARDPSM/g PSM, respectively). The negative effect of L-mimosine on $\mathrm{OM}$ degradability was supported by in vitro incubations with straw and inoculum from Belgian sheep, as ruminal degradation of straw was $31 \%$ lower when L-mimosine was supplemented.

\section{Introduction}

The restricted availability of concentrates accompanied with limited availability of good quality forage mainly in the dry season hampers Cuban and generally tropical livestock production (Lima et al. 2011). Hence, tropical legumes are considered a valuable resource to enhance livestock productivity (LimaOrozco et al. 2014, Mohamed et al. 2018, Soltan et al. 2017). However, they contain plant secondary metabolites (PSM) that may have negative effects on the rumen microbial community (Makkar et al. 2007b), cellular proliferation (Nguyen and Tawata 2016), organic matter (OM) degradability in the rumen, nutrient assimilation, animal performance and/or health (Janardhanan et al. 2003, Makkar, et al. 2007b).

Nevertheless, most of the studies towards anti-nutritional effects of tropical legumes have been performed in monogastric animals (Belmar et al. 2007, Siddhuraju et al. 1996), as ruminants are thought to tolerate these legumes to some extent due to degradation or inactivation of their PSM by ruminal microbiota, rendering the PSM anti-nutritive properties ineffective (Dominguez-Bello and Stewart 1990a, Hoffmann et al. 2003, Shelton et al. 2019). However, this implies that the extent of ruminal degradation of PSM might depend on the presence in the rumen microbial population of specialist microbes (Weimer 2015). As such, geographical differences in the rumen microbial ecosystem have been previously shown and related to the differences in the capacity of a ruminal breakdown of specific PSM [e.g. the L-mimosine breakdown by Hawaiian (Allison et al. 1990, Jones and Megarrity 1986) and Indian (Vaithiyanathan et al. 2005), but not by Australian ruminants (Jones and Megarrity 1986)]. 
Hence, we hypothesized that the apparent ruminal degradability of organic matter (ARDOM) and PSM (ARDPSM) of tropical legumes would depend on the source of ruminal inocula and the type of PSM. Accordingly, the aim of the current in vitro study was to concomitantly assess the apparent ruminal degradability of organic matter (ARDOM) and PSM (ARDPSM) of three tropical legumes (M. pruriens, $C$. ensiformis, and $L$. leucocephala) using different sources of ruminal inocula.

\section{Material And Methods}

\subsection{Experimental site, legumes and sample collection}

The three tropical legumes were sown in Santa Clara, in the center of Cuba $\left(22^{\circ} 25^{\prime} 22.9^{\prime \prime} \mathrm{N}, 80^{\circ} 03^{\prime} 13^{\prime \prime} \mathrm{W}\right)$. M. pruriens was sown intercropped with elephant grass (Pennisetum purpureum) in a field with an area of 1 ha. $C$. ensiformis and $L$. leucocephala were sown in different plots ( 0.2 and 1 ha, respectively). Average precipitation, temperature and humidity during the cropping period were $47.5 \pm 42.13 \mathrm{~mm}, 26.3 \pm 2.02{ }^{\circ} \mathrm{C}$ and $82.5 \pm 4.19 \%$, respectively. Crops were not fertilized nor irrigated. The forage of the three tropical legumes was harvested around noon at the end of the wet season (between 23/10/2014 and 27/10/2014). M. pruriens and C. ensiformis were harvested about $5 \mathrm{~cm}$ above the soil (at flowering stage), and $L$. leucocephala forage was cut from young branches (stems were removed to obtain only the twigs and leaves). Beans from $M$. pruriens and $C$. ensiformis were obtained from the same plots at the dry bean stage. Forage and beans were dried in a furnace at $65^{\circ} \mathrm{C}$ for 72 hours. Dried material was ground and passed through a screen with mesh size of $0.1 \mathrm{~cm}$ to obtain both forage and bean meals. Bean meals of $M$. pruriens and $C$. ensiformis have been considered in the experiment focusing on PSM degradation kinetics as PSM particularly accumulate in beans, which consequently have a higher PSM concentration. Additionally, mixtures of beans and forage (1:1, DM basis) of either $C$. ensiformis or $M$. pruriens were prepared. This mixture is assumed to represent the maximum amount of beans which could be obtained in practice when concomitantly harvesting forage and beans at the hard dough stage of the beans (Díaz et al. 2003). L. leucocephala forage was used to prepare a forage meal. As such, three different types of meals were available for further testing, i.e. forage/bean (1:1)a meal consisting of beans and forage $(1: 1 ; \mathrm{w} / \mathrm{w})$ (C. ensiformis and $M$. pruriens), forage meal ( $L$. leucocephala) and bean meals ( $C$. ensiformis and $M$. pruriens). These meals were stored in wide-mouth glass jars with a metal cap in a dry room at ambient temperature until use. A subsample of each different type of meal was transported separately at ambient temperature in a heat-sealed plastic bag to Belgium for analysis of PSM and to perform in vitro incubations.

\subsection{Chemical analysis}

\subsubsection{Proximate chemical analysis.}

Proximate chemical analysis of the beans, forage/bean (1:1) meal and forage meal (Table 1) was done according to AOAC (2005) (DM: dry matter - ID number 930.15; CP: crude protein - as $6.25 \times \mathrm{N}$ - ID number 954.01); OM: organic matter (EC 2009) and fiber fractioning by Van Soest et al. (1991) (NDFom: neutral detergent fiber not assayed with a heat stable amylase and expressed exclusive of residual ash, ADFom: 
acid detergent fiber expressed exclusive of residual ash, lignin ( $\mathrm{pm}$ ) was determined from the residue of the ADFom analysis with lignin being oxidized by permanganate). Hemicellulose was calculated as the difference of NDFom and ADFom, while cellulose was calculated as the difference of ADFom and lignin (pm).

\subsubsection{Plant secondary metabolites.}

Before and after the in vitro incubation with rumen fluid of either the bean meal, the forage/bean (1:1) meals or the forage meal, trypsin inhibitor (TI), L-canavanine, and L-mimosine were analyzed as described by Makkar, et al. (2007b), and Con A was determined by ELISA following the protocol provided by the manufacturer of the kit (Abbexa Ltd., Cambridge Science Park, Cambridge, CB4 OEY, UK). As such, the degradability of those PSM was assessed as follow:

\section{$\operatorname{ARDPSM}(\mathrm{g} / \mathrm{g})^{*}=\mathrm{PSM}$ content (after incubation)/PSM content (before incubation)}

with ARDPSM is the apparent degradability of the plant secondary metabolite ${ }^{*} \mathrm{~g} / \mathrm{g}$ except for $\mathrm{TI}$ [trypsin inhibitor units (TIU)/TIU], and with PSM content expressed as ([TIU/kg DM] for TI and [g/kg DM] for Lcanavanine, L-mimosine and Con A).

\subsection{In vitro ruminal degradation and breakdown of PSM of three tropical legumes using different inoculum sources (Experiment 1)}

2.3.1. Single end-point $(24 \mathrm{~h})$ in vitro rumen degradability and breakdown of PSM of the three tropical legumes using fresh inoculum from Belgian sheep (Experiment 1.1)

Incubations were carried out following the method described by Vlaeminck et al. (2014). Prior to the incubation period, rumen fluid was collected before feeding from three rumen fistulated crossbred sheep (Texel $x$ Belgian milk sheep). After anaerobic transport to the laboratory, the rumen fluid of the three sheep was mixed and filtered through a sieve with a pore size of $1 \mathrm{~mm}$ under continuous $\mathrm{CO}_{2}$ flushing where after it was kept anaerobically in a water bath at $39{ }^{\circ} \mathrm{C}$ to be transferred to the incubation flask after mixing anaerobically and $\mathrm{CO}_{2}$ saturated (flushed overnight under $\mathrm{CO}_{2}$ atmosphere) mixed bicarbonate/phosphate buffer at a rumen fluid/buffer ratio of $263.2 \mathrm{~mL} / \mathrm{L}$ (Castro-Montoya et al. 2015). Each $120 \mathrm{~mL}$ incubation flask contained $250 \mathrm{mg}$ of dry material of either forage/bean (1:1) meal of $C$. ensiformis or M. pruriens or forage meal of L. leucocephala (Figure 1A). Each treatment was incubated in triplicate at $39^{\circ} \mathrm{C}$ in an incubator with intermittent shaking (Edmund Bühler GmbH SM - 30 Control, Germany) and all flasks were removed from the incubator after $24 \mathrm{~h}$. At the end of the $24 \mathrm{~h}$-incubation, all flasks were removed from the incubator, and the fermentation activity was stopped through transfer of the flask to an ice bath. After $5 \mathrm{~min}$, the liquid content was sampled $(2 \mathrm{~mL})$ and acidified with $0.2 \mathrm{~mL}$ of formic acid that contained the internal standard (10 mg of 2-ethylbutyric acid/mL formic acid) for short chain fatty acids (SCFA) analysis. After 15 min of centrifugation $\left(4{ }^{\circ} \mathrm{C}, 22,000 \times \mathrm{g}\right.$ [Beckman Coulter, Avanti J-E model, CA, USA]), the supernatant was filtered and an aliquot was transferred into a $2 \mathrm{~mL}$ glass vial (Castro-Montoya et al. 2012). Samples were stored at $4{ }^{\circ} \mathrm{C}$ until analysis using a gas chromatograph 
(HP 7890A, Agilent Technologies, Diegem, Belgium). The leftover was stored at $-20^{\circ} \mathrm{C}$ until the measurement of the PSM as described before (section 2.2.2).

2.3.2. Single end-point ( $24 h$ ) in vitro rumen degradability and breakdown of PSM of the three tropical legumes using fresh inoculum from Cuban sheep (Experiment 1.2)

This experiment was carried out to assess the concomitant ruminal degradation of OM and PSM using inoculum from another geographical origin. The incubations with inoculum from Cuban sheep was carried out in Santa Clara, Cuba $\left(22^{\circ} 24^{\prime} 49^{\prime \prime} N 79^{\circ} 57^{\prime} 58^{\prime \prime} \mathrm{O}\right)$. Rumen fluid was obtained before feeding by an esophageal tube from three Cuban Pelibuey sheep following the recommendation approved by the ethical committee of the Faculty of Veterinary Medicine, Ghent University, Belgium (approval number EC2015/12). Cuban sheep were grazing native grasses (Andropogon spp., Cynodon nlemfluensis, Paspalum notatum, Panicum maximum) and had free access to drinking water. Each $120 \mathrm{~mL}$ incubation flask contained $250 \mathrm{mg}$ of dry material of either the forage/bean (1:1) meal of $C$. ensiformis or $M$. pruriens or the forage meal of $L$. leucocephala (Figure $1 \mathrm{~A}$ ). The preparation of the rumen fluid/buffer mixture and the $24 \mathrm{~h}$ incubation were as explained before (section 2.3.1). Each treatment was incubated in triplicate at $39^{\circ} \mathrm{C}$ in an incubator (Memmert B40, Germany) additionally equipped with a shaker (OrbitTM Digital Shakers, USA) for intermittent shaking. All flasks were removed from the incubator after $24 \mathrm{~h}$, and the fermentation activity was stopped through transfer of the flasks to an ice bath. After 5 min, samples were snap-frozen until the preparation for further analysis. Prior to shipment to Belgium, samples were thawed and prepared for analysis of SCFA as described before (Castro-Montoya, et al. 2012), stored at $4{ }^{\circ} \mathrm{C}$ and transported under cold conditions. The SCFA production was measured as explained in experiment 1.1 , and the leftover was stored at $-20^{\circ} \mathrm{C}$ until the measurement of the PSM as described before (section 2.2.2).

\subsection{In vitro kinetics of ruminal degradation and breakdown of PSM from bean and forage meal of three tropical legumes using fresh inoculum from Belgian sheep (Experiment 2)}

The kinetic study was used to assess the concomitant effect of PSM and OM degradation in time, using the plant parts with the highest PSM content (i.e. beans in the case of $C$. ensiformis and M. pruriens). Prior to the incubation period, rumen fluid was collected before feeding from three rumen fistulated crossbred sheep (Texel x Belgian milk sheep) and treated as explained previously (section 2.3.1). The 24 $\mathrm{h}$ in vitro rumen incubations, were carried out following the method described by Vlaeminck, et al. (2014). Each $120 \mathrm{~mL}$ incubation flask contained $250 \mathrm{mg}$ of dry material of either bean meal of $C$. ensiformis or M. pruriens or forage meal of $L$. leucocephala (Figure 1B). All flasks were incubated in triplicate during 0 , $2,4,6,8,10,12$ and $24 \mathrm{~h}$ at $39^{\circ} \mathrm{C}$ in an incubator with intermittent shaking (Edmund Bühler GmbH SM 30 Control, Germany). At the end of each incubation time, the fermentation was stopped and samples of rumen fluid were prepared for SCFA as described in experiment 1.1 , and the leftover was stored at $-20^{\circ} \mathrm{C}$ until the measurement of the PSM as described before (section 2.2.2).

\subsection{Effect of L-mimosine on the ruminal degradation kinetics of straw using fresh inoculum from Belgian sheep (Experiment 3)}


This experiment was carried out to assess whether L-mimosine directly affects ruminal degradability of fibrous rich feedstuffs. Prior to the incubation, rumen fluid was collected from three rumen fistulated crossbred sheep (Texel x Belgian milk sheep) as explained by Vlaeminck, et al. (2014). The $24 \mathrm{~h}$ in vitro rumen incubations, were carried out following the method described in the experiment 2 , although the volume of the incubation flask $(25 \mathrm{~mL})$ as well as the amount of buffer, rumen fluid and substrate $(52 \mathrm{mg}$ DM of straw) was five times smaller. Incubations in such smaller volumes have been carried out before by our group and do not change the incubation outcome (Debevere et al. 2020). The smaller volume has been applied here to limit the amount of pure L-mimosine required. Straw was incubated with or without L-mimosine (purity $\geq 98 \%$, Sigma-Aldrich Pty Ltd, St Louis, MO, USA) at the same concentration present in the L. leucocephala forage meal used in this study (Table 1). All flasks were incubated in triplicate during $0,2,6,10$ and $24 \mathrm{~h}$ at $39^{\circ} \mathrm{C}$ in an incubator with intermittent shaking (Edmund Bühler GmbH SM 30 Control, Germany). At the end of each incubation time, the fermentation was stopped and samples of rumen fluid were prepared for SCFA analysis as described in experiment 1.1.

\subsection{Apparently rumen organic matter degradability (ARDOM)}

ARDOM was calculated based on the stoichiometrical equation representing carbohydrate breakdown as:

$\operatorname{ARDOM}(\mathrm{g} / 100 \mathrm{~g}$ OM$)=($ acetate $/ 2+$ propionate $/ 2+$ butyrate+caproate $) \times 162$

[2]

with 162 as the assumed molecular weight of 1 mol of fermented carbohydrates; net production of acetate, propionate, butyrate and caproate expressed in mol/100 g OM of substrate added (Demeyer 1991). As compared with the stoichiometric relationship described previously, caproate was included in the equation based on the same stoichiometric principles of SCFA formation from the carbohydrate fermentation as outlined by Demeyer (1991).

\subsection{Kinetic parameters and statistical analysis}

All statistical analyses were performed with SPSS 21.0 (SPSS. 2012). Using nonlinear regression, the ARDOM and ARDSPM kinetics was estimated according to Schofield (2000) with some modifications:

$$
\text { ARDOMt or ARDPSMt }=\text { Ass } /\{1+\exp [2-4 \times k f \times(t-L n)]\}
$$

with ARDOMt or ARDPSMt ( $\mathrm{g} / \mathrm{g}$ except for TI [TIU/TIU]) ARDOM and ARDPSM at time (t); Ass, the asymptotic ARDOM or ARDSPM corresponding to maximum OM or PSM degradation, respectively $(\mathrm{g} / \mathrm{g}$ except for TI [TIU/TIU], respectively); $k f$, the fractional ARDOM and ARDPSM rate $\left(\mathrm{h}^{-1}\right), \mathrm{t}$, the incubation time (h) and Ln, the lag time before degradation starts (h). A graph was plotted together with the observed values to show the trend of the degradation curve. Further, a One way ANOVA was applied to assess the differences between kinetic parameters within and between the tropical legumes. Differences were declared significant at $\mathrm{P}<0.05$ and a Tukey's test for multiple comparison was run. 
Additionally, a One way ANOVA was applied: a) to assess the effects of the legume type on ARDOM and ARDSPM in the single end-point ( $24 \mathrm{~h})$ in vitro rumen incubation using Belgian or Cuban sheep inocula; and $b$ ) to assess the effects of the addition of L-mimosine on ARDOM and SCFA production in $24 \mathrm{~h}$ in vitro ruminal fermentation of straw. Differences were declared significant at $\mathrm{P}<0.05$ and Tukey's test for multiple comparison was run.

\section{Results}

Different in vitro approaches were combined in 3 experiments (Figure 1) to assess whether ruminal degradation of three legume meals (i.e. C. ensiformis, M. pruriens and L. leucocephala) was influenced by the source of ruminal inoculum and whether ruminal OM and PSM degradation occurred concomitantly or independently. The latter was assessed from the results of the in vitro kinetic studies with either the legumes or with pure PSM under Belgian conditions. Further, the single-end-point $24 \mathrm{~h}$ batch incubation also was performed using Cuban sheep inoculum to verify the association of the PSM breakdown with the OM degradability using inoculum from another source. In case the results of both experiments suggest such an association, the direct effect of the PSM on the ARDOM kinetics was assessed using pure PSM added to a PSM-free fibrous substrate.

\subsection{Experiment 1. In vitro ruminal degradation and breakdown of PSM of three tropical legumes using different inoculum sources}

Experiment 1.1. Single end-point $(24 \mathrm{~h})$ in vitro rumen degradability and breakdown of PSM of three tropical legumes using fresh inoculum from Belgian sheep

The ARDOM and ARDPSM results of the three tropical legumes using ruminal inoculum from Belgian sheep are shown in the Table 2. The ARDOM and ARDPSM of the forage/bean (1:1) meal of $C$. ensiformis and $M$. pruriens were similar, with almost complete degradation of their PSM. Additionally, forage meal of $L$. leucocephala was the least $(P<0.05)$ degradable of the three legume meals $(0.20 \mathrm{~g}$ ARDOM/g OM), while L-mimosine even was hardly degraded after $24 \mathrm{~h}(0.05 \mathrm{~g} / \mathrm{g})$. The fermentation pattern of the meals of the three tropical legumes differed. Fermentation of L. leucocephala resulted in higher molar acetate and propionate proportions, at the expense of molar proportions of butyrate and isoacids, valerate and caproate. On the contrary, the fermentation of $M$. pruriens resulted in higher proportions of butyrate and isoacids, valerate and caproate and was associated with lower molar acetate and propionate proportions. The fermentation pattern of $C$. ensiformis was intermediate.

Experiment 1.2. Single end-point $(24 \mathrm{~h})$ in vitro rumen degradability and breakdown of PSM of three tropical legumes using fresh inoculum from Cuban sheep

The ARDOM and ARDPSM of the forage/bean (1:1) meal of $C$. ensiformis and $M$. pruriens and the forage of $L$. leucocephala with Cuban sheep inoculum are presented in Table 3. Degradation of the $M$. pruriens forage/bean (1:1) meal was most extensive, while degradability of the forage meal of $L$. leucocephala was lowest, in agreement with the observations in experiment 1.1. In addition, as observed 
in the experiment 1.1, the degradation of PSM in the forage/bean (1:1) meal of $C$. ensiformis and $M$. pruriens was almost complete. However, that was not the case for the PSM of the forage meal of $L$. leucocephala, although L-mimosine seemed to be more extensively degraded under the Cuban incubation conditions compared with the Belgian conditions in experiment 1.1. The fermentation patterns of the meals of the three tropical legumes differed with the exception of the molar propionate proportion $(P>$ $0.05)$. Fermentation of $L$. leucocephala resulted in a greater molar acetate proportion, while the lowest molar butyrate proportion was observed in the fermentation of $C$. ensiformis. Further, the molar proportion of isoacids, valerate and caproate were lowest in the fermentation of L. leucocephala.

\subsection{Experiment 2. In vitro kinetics of ruminal degradation and breakdown of PSM from bean and forage meal of three tropical legumes using fresh inoculum from Belgian sheep}

The extensive ARDOM and ARDPSM of the forage/bean (1:1) meal of $C$. ensiformis and $M$. pruriens after 24h of incubation (experiment 1.1) does not necessarily imply similar kinetics of PSM and OM breakdown. Therefore, in vitro degradation kinetics were studied and presented in Table 4 and Figures 2, 3 and 4 . As the PSM, quantified in this study, are enriched in the beans of $C$. ensiformis and $M$. pruriens, in this kinetic study, bean meals rather than forage/bean (1:1) meals were used for these two legumes. Within each legume meal, the kinetic parameters of the OM and PSM in vitro ruminal degradation were compared (Table 4). In the case of L. leucocephala forage meal the lag time and degradation rate of ARDOM and ARDSPM did not differ. On the contrary, for both other legumes the lag time and degradation rate of ARDOM and ARDPSM differed considerably. The apparent in vitro OM degradability of the bean meals from $C$. ensiformis and $M$. pruriens followed a similar and quite linear pattern reaching 0.84 and $0.75 \mathrm{~g} \mathrm{ARDOM} / \mathrm{g}$ OM after $24 \mathrm{~h}$ of incubation, respectively. The apparent in vitro OM degradability of $L$. leucocephala forage meal was considerably lower, reaching a maximum of $0.22 \mathrm{~g}$ ARDOM/g OM after 24 h. Lag time and degradation rate of ARDOM did not differ between legumes $(P>0.05)$. Degradation of TI from bean meals showed a lag time of about $6 \mathrm{~h}$, but degradation increased sharply between 6 and $10 \mathrm{~h}$ of incubation and reached a plateau after $12 \mathrm{~h}$ of incubation (Figure 2 and 3). Strikingly, the TI degradation pattern of the forage meal of $L$. leucocephala forage differed compared to the other two legumes (Table 4) as no lag time was observed (Figure 4) and a maximum degradation of about 0.62 TIU/TIU was reached after 10 to $12 \mathrm{~h}$ of incubation. L-canavanine degradation did not differ between both bean meals $(P>0.05)$. L-canavanine was extensively degraded after $24 \mathrm{~h}(>0.80 \mathrm{~g} / \mathrm{g})$ despite a lag time of $12 \mathrm{~h}$ in $C$. ensiformis versus the quite linear degradation kinetics in $M$. pruriens. In addition, Con $A$ (only detected in $C$. ensiformis bean meal, Table 1$)$ was fastly $(0.70 \mathrm{~g} / \mathrm{g}$ in the first $2 \mathrm{~h}$ of incubation) and extensively ( $0.95 \mathrm{~g} / \mathrm{g}$ after $24 \mathrm{~h}$ ) degraded (data not shown). In contrast, L-mimosine and its intermediates in the $L$. leucocephala forage meal incubation were hardly degraded $(0.05 \mathrm{~g} / \mathrm{g})$ and the maximum degradation was already reached during the first $2 \mathrm{~h}$ of incubation (Figure 4).

\subsection{Experiment 3. Effect of L-mimosine on the ruminal degradation kinetics of straw using fresh inoculum from Belgian sheep}


In experiments 1 and 2, the extent of ruminal degradation of L-mimosine was considerably different between the Belgian and the Cuban set-up. Concomitantly, overall OM degradation of the legume containing L-mimosine, i.e. L. leucocephala, differed in these two incubations. Accordingly, it is unclear whether L-mimosine impaired overall OM degradation or vice versa, whether L-mimosine degradation was impaired because of limited degradation of the L. leucocephala forage meal. Hence, the effect of pure Lmimosine on the ruminal degradation of a fibrous feed resource was assessed. The kinetics of ARDOM of straw without and with L-mimosine are presented in Figure 5. The apparent ruminal OM degradability of straw was affected by the addition of L-mimosine. After $24 \mathrm{~h}$ of incubation, ARDOM was 1.45 times

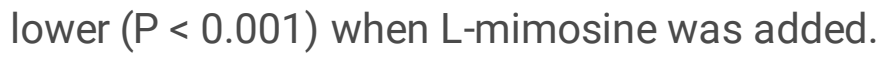

\section{Discussion}

\subsection{Characteristics of the tropical legume batches used in the current experiment}

The CP content of the three tropical legumes investigated in the present study exceeded $200 \mathrm{~g} / \mathrm{kg} \mathrm{DM}$, which is of interest to supplement the poor quality tropical forages with low CP contents (Ahmed et al. 2018, Njidda and Nasiru 2010). Nevertheless, L. leucocephala forage meal contained high amounts of fiber (mainly ADFom and lignin (pm)) which limits its metabolisable energy content (Du et al. 2016, Moore and Jung 2001). The PSM content of plants partially reflects their adaptation to their environment and defense against natural enemies, such as competitors, pathogens, and/or herbivores (Makkar et al. 2007a). As such, variation in PSM content may be related to different biotic and abiotic conditions, as well as plant genetics and phenology (Estell 2010, García et al. 2008, Soedarjo and Borthakur 1996). Compared to the bean and forage meals of the present study, others, e.g. Belmar, et al. (2007), reported higher concentrations in C. ensiformis bean meal of L-canavanine $(50.8 \mathrm{mg} / \mathrm{g}$ DM), whereas Agbede and Aletor (2005) showed lower TI contents (2.1 TIU/g DM). Additionally, García, et al. (2008) and Honda and Borthakur (2019) reported a considerably lower content (20.4 - $69.5 \mathrm{~g} / \mathrm{kg} \mathrm{DM}$ ) of L-mimosine than reported in the L. leucocephala forage meal of the present study. Literature on PSM in $M$. pruriens beans or forage/bean (1:1) meal are scarce which might be related to the reported absence of L-canavanine (Lackey 1977). However, in the present study, the content of L-canavanine in M. pruriens was similar to that in $C$. ensiformis, which is in line with the low concentration of L-canavanine in Mucuna spp. reported by Udoh and Ekpenyong (2001).

\subsection{Apparent degradation of three tropical legumes in relation to source of the ruminal inoculum and degradation of their PSM}

In experiment 1, fresh ruminal inoculum was obtained from Belgian and Cuban sheep. Although the incubated substrate as well as the in vitro set-up was the same in Belgium and Cuba, the two incubations were not compared statistically, as they did not take place at the same time and under the same lab conditions. Also collection of the ruminal inoculum differed. Nevertheless, obvious inoculum-related differences in ARDOM within a legume source were interpreted as an indication of the a need for specific ruminal conditions to be fulfilled to ensure optimal ruminal degradation of this legume and their PSM. 
Overall degradation (i.e. ARDOM) of the forage/bean (1:1) meal of $C$. ensiformis was not affected by the source of the inoculum. Additionally, both the Belgian as well as the Cuban sheep inoculum extensively degraded the PSM in this legume ( $\mathrm{TI}$ and L-canavanine) during a 24h-incubation. Organic matter degradability was in line with formerly reported in vitro degradation rates (Ajayi et al. 2009), while the potential of the microbial population in the rumen to detoxify L-canavanine also has been suggested by Dominguez-Bello and Stewart (1990b). In line with $C$. ensiformis, the degradation of PSM in $M$. pruriens forage/bean (1:1) meal ( $\mathrm{TI}$ and L-canavanine) was almost complete both during the $24 \mathrm{~h}$ incubation performed in Belgium as well as in Cuba.

L. leucocephala forage meal was only poorly degraded in the current study. Low degradation rates obviously are related to the high fiber content and particularly a high amount of lignin (> $100 \mathrm{~g} / \mathrm{kg} \mathrm{DM}$ ) and its detrimental effects on degradability (Du, et al. 2016). Nevertheless, values obtained under Belgian incubation conditions ( 0.20 and 0.22 after $24 \mathrm{~h}$ incubation) were considerably lower than in other reports (Gaviria et al. 2015, Soltan, et al. 2017, Soltan et al. 2013). Furthermore, Cuban in vitro incubations showed a higher ARDOM (0.35) compared with Belgian incubations. This could be related to a better adaptation of the microbiome in the Cuban sheep inoculum to degrade fibrous feeds as shown by Cherney et al. (1993). Additionally, the extensive degradation of L-mimosine could have played a role in this case. Although concomitant occurrence of increased ARDOM and enhanced degradation of Lmimosine, does not proof a causal effect, results of experiment 3 showed supplementation of Lmimosine could significantly reduce in vitro ARDOM of a fibrous feedstuff. In line with this, others reported some anti-microbial effect of L-mimosine and DHP (Anitha et al. 2005, Rodgers et al. 2017), particularly towards fungi and Gram-positive bacteria, which might have impaired the degradability of this legume. Accordingly, the limited breakdown of L-mimosine in L. leucocephala during the Belgian 24 h-incubations may have reduced the overall OM degradability of this legume, while the increased ARDOM in the Cuban $24 \mathrm{~h}$-incubations concomitantly occurred with a more extensive degradation of L-mimosine. This may be related to the presence of L-mimosine and DHP degrading ruminal bacteria (Galindo et al. 2009). In this respect, Synergistes jonesii is supposed to be the main ruminal bacteria responsible for the degradation of DHP (Allison, et al. 1990), although also other ruminal bacteria (e.g. Streptococcus lutetiensis, Clostridium butyricum, Lactobacillus vitulinus) are capable to degrade these metabolites (Derakhshani et al. 2016). Degradation of L-mimosine by ruminal fluid from sheep which grazed tropical pastures including L. leucoecephala also could explain why Soltan, et al. (2017) did not observe any negative effect of L-mimosine on the OM degradation of lucerne (Medicago sativa) hay, while ruminal degradation of Bermuda grass (Cynodon dactylon L. Pers.; hybrid "Tifton-85") even increased by $10 \%$ upon L-mimosine supplementation (11.6 mg/g DM).

The association between ARDOM and ARDPSM was further investigated in a kinetic assessment. For this, bean meals of $C$. ensiformis and $M$. pruriens were incubated, as particularly the beans of these legumes are rich in PSM. Organic matter breakdown started almost immediately, without major lag time in each of the tropical legumes, while the PSM degradation (Trypsin inhibitor in $C$. ensiformis and $M$. pruriens; and L-canavanine in $C$. ensiformis) was considerably delayed. Thus, inocula did not need to break down the plant secondary metabolites prior to the start of OM degradation. Trypsin inhibitor was 
extensively degraded after $10 \mathrm{~h}$ of incubation for the three tropical legumes. Considering an average retention time in the rumen of about $12-14 \mathrm{~h}$ for legume beans (based on soybean data) and of about $16-20 \mathrm{~h}$ for forages (Gao et al. 2015), our data suggest that only a negligible amount of TI would bypass the rumen. As such, the trypsin inhibitor is not expected to reduce protein digestibility in the small intestine. In contrast to the other two legumes, for $L$. leucocephala, kinetics of ARDOM and apparently ruminal degradation of L-mimosine show a similar pattern (Table 4). As in single-end point incubations with ruminal inoculum of Belgian sheep, L-mimosine was hardly degraded in the kinetic study. This kinetic association could be partially due to the toxic effects of L-mimosine or its intermediates on the ruminal microbiome, as indicated by results of experiment 3 and suggested from literature (Ghosh and Samiran 2007, Rosenthal 1991).

\section{Conclusion}

C. ensiformis and M. pruriens (beans and forage/bean (1:1) meal), as well as their PSM (i.e. trypsin inhibitor and L-canavanine) were extensively degraded. Nevertheless, in some cases PSM degradation was characterized by a lag time, while this was not observed for OM degradation. On the other hand, $L$. leucocephala degradability could partially depend on the potential of the rumen microbes to degrade Lmimosine.

\section{Abbreviations}

ADFom, acid detergent fiber expressed exclusive of residual ash; ARDOM, apparent in vitro rumen degradability of organic matter; ARDSPM, apparent rumen degradability of plant secondary metabolites; Con A, concanavaline A; DM, dry matter; ha, hectare; ME, metabolisable energy; NDFom, neutral detergent fiber not assayed with a heat stable amylase and expressed exclusive of residual ash; NPAA, non-protein amino acids; OM, organic matter; $\mathrm{CP}$, crude protein; PCA, proximate chemical analysis; PSM, plant secondary metabolites; SCFA, short chain fatty acids; TI, trypsin inhibitor.

\section{Declarations}

Author Contributions: Conceptualization, methodology, and supervision V. F., R. L-O., and E. A-O.; Formal analysis E. A-O.; Investigation E. A-O., P.Y. F-R., R. L-O., and B. R-B.; Writing - original draft E. A-O.; Writing review \& editing V. F., R. L-O.; project administration and funding acquisition V. F., R. L-O.

All authors have read and agreed to the published version of the manuscript.

\section{CONFLICT OF INTEREST STATEMENT}

The authors declare that the research was conducted in the absence of any commercial or financial relationships that could be construed as a potential conflict of interest.

DATA AVAILABILITY STATEMENT (DAS) 
Data availability - Not Applicable

\section{ACKNOWLEDGEMENTS}

This research was supported by the special research fund for developing countries (BOF scholarship: BOF.DCV.2014.0009.01) of Ghent University, Belgium, and Universidad Central "Marta Abreu" de Las Villas (UCLV), Cuba (Project No. 10042) and National Program of Basic Sciences (Project No: P223LH001-025), and the VLIR-UOS partner program (ZEIN2015RIP29) for Institutional University Cooperation between UCLV, Cuba, and Flemish universities. Special acknowledgements to the staff of the Laboratory for Animal Nutrition and Animal Product Quality of Ghent University, and the Laboratory for Animal Nutrition and the Clinical Laboratory at Facultad de Ciencias Agropecuarias (UCLV), Cuba, for the technical assistance during this research.

\section{ANIMAL WELFARE STATEMENT}

The authors confirm that the ethical policies of the journal, as noted on the journal's author guidelines page, have been adhered to. All experimental procedures with fistulated sheep were conducted and approved by the ethical commission of the Institute for Agricultural and Fisheries Research (ILVO) [approval number EC2014_222], in accordance with the European Directive (EU) No 241/2014.

\section{References}

Agbede, J.O., and Aletor, V.A., 2005. Studies of the chemical composition and protein quality evaluation of differently processed Canavalia ensiformis and Mucuna pruriens seed flours, Journal of Food Composition and Analysis, 18, 89-103

Ahmed, M. et al., 2018. Nutritive and anti-nutritive evaluation of Kleinhovia hospita, Leucaena leucocephala and Gliricidia sepium with respect to their effects on in vitro rumen fermentation and gas production, Tropical Animal Science Journal, 41, 128-136

Ajayi, F. et al., 2009. Assessment of seven under-utilized grain legume foliages as feed resources for ruminants, Livestock Research for Rural Development, 21, 149-156

Allison, M.J., Hammond, A.C., and Jones, R.J., 1990. Detection of ruminal bacteria that degrade toxic dihydroxypyridine compounds produced from mimosine, Appl Environ Microbiol, 56, 590-594

Anitha, R., Jayavelu, S., and Murugesan, K., 2005. Antidermatophytic and bacterial activity of mimosine, Phytotherapy Research, 19, 992-993

AOAC, 2005. Official methods of analysis of AOAC International, (AOAC International, Gaithersburg, Maryland, USA.)

Belmar, R. et al., 2007. Jack bean (Canavalia ensifomis L. DC) in poultry diets: antinutritional factors and detoxification studies - a review, World's Poultry Science Journal, 55, 37-59 
Castro-Montoya, J. et al., 2012. Interactions between methane mitigation additives and basal substrates on in vitro methane and VFA production, Animal Feed Science and Technology, 176, 47-60

Castro-Montoya, J. et al., 2015. In vivo and in vitro effects of a blend of essential oils on rumen methane mitigation, Livestock Science, 180, 134-142

Cherney, D., Siciliano-Jones, J., and Pell, A., 1993. Forage in vitro dry matter digestibility as influenced by fiber source in the donor cow diet, J Anim Sci, 71, 1335-1338

Debevere, S. et al., 2020. In vitro rumen simulations show a reduced disappearance of deoxynivalenol, nivalenol and enniatin $b$ at conditions of rumen acidosis and lower microbial activity, Toxins, 12, 101

Demeyer, D., 1991. Quantitative aspects of microbial metabolism on rumen and hindgut. In: J.P. Jouany (ed), Rumen microbial metabolism and ruminant digestion, 1991, INRA. Paris, France), 217-237

Derakhshani, H., Corley, S.W., and Al Jassim, R., 2016. Isolation and characterization of mimosine, 3, 4 DHP and 2, 3 DHP degrading bacteria from a commercial rumen inoculum, Journal of Basic Microbiology, $56,580-585$

Díaz, M.F. et al., 2003. Comportamiento de la producción de forrajes y granos de Canavalia ensiformis, Lablab purpureus y Stizolobium niveum en siembras de septiembre, Revista Cubana de Ciencia Agrícola, $37,65-71$

Dominguez-Bello, M.G., and Stewart, C.S., 1990a. Degradation of mimosine, 2,3-dihydroxy pyridine and 3hydroxy-4(1H)-pyridine by bacteria from the rumen of sheep in Venezuela, FEMS Microbiol Ecol, 6, 283289

Dominguez-Bello, M.G., and Stewart, C.S., 1990b. Effects of feeding Canavalia ensiformis on the rumen flora of sheep, and of the toxic amino acid canavanine on rumen bacteria, Systematic and Applied Microbiology, 13, 388-393

Du, S., Xu, M., and Yao, J., 2016. Relationship between fibre degradation kinetics and chemical composition of forages and by-products in ruminants, Journal of Applied Animal Research, 44, 189-193

EC, 2009. European Union Official Diary. Reglament (CE) no152/2009., 2009, (European Community Committee, Brusselas, Belgium), 54

Estell, R., 2010. Coping with shrub secondary metabolites by ruminants, Small Ruminant Research, 94, 19

Galindo, J. et al., 2009. Efecto de una mezcla múltiple de leguminosas herbáceas y Leucaena leucocephala en la población microbiana y productos fermentativos del rumen de añojos mestizos de Cebú, Revista Cubana de Ciencia Agrícola, 43, 
Gao, W. et al., 2015. Rumen degradability and post-ruminal digestion of dry matter, nitrogen and amino acids of three protein supplements, Asian-Australas J Anim Sci, 28, 485-493

García, D. et al., 2008. Caracterización de diez cultivares forrajeros de Leucaena leucocephala basada en la composición química y la degradabilidad ruminal, Revista MVZ Córdoba, 13, 1295-1303

Gaviria, X., Naranjo, J.F., and Barahona, R., 2015. In vitro fermentation kinetics of Leucaena leucocephala and Megathyrsus maximus and their mixtures, with or without energy supplementation, Pastures and Forages., 8, 55-63

Ghosh, M.K., and Samiran, B., 2007. Mimosine toxicity-a problem of Leucaena feeding in ruminants, Asian Journal of Animal and Veterinary Advances, 2, 63-73

Hoffmann, E.M., Muetzel, S., and Becker, K., 2003. The fermentation of soybean meal by rumen microbes in vitro reveals different kinetic features for the inactivation and the degradation of trypsin inhibitor protein, Animal Feed Science and Technology, 106, 189-197

Honda, M.D., and Borthakur, D., 2019. Mimosine concentration in Leucaena leucocephala under various environmental conditions, Tropical Grasslands-Forrajes Tropicales, 7, 164-172

Janardhanan, K., Gurumoorthi, P., and Pugalenthi, M., 2003. Nutritional potential of five accessions of a South Indian tribal pulse, Mucuna pruriens var utilis I. The effect of processing methods on the content of I-dopa, phytic acid, and oligosaccharides, Tropical and Subtropical Agroecosystems, 1, 141-152

Jones, R.J., and Megarrity, R.G., 1986. Successful transfer of DHP-degrading bacteria from Hawaiian goats to Australian ruminants to overcome the toxicity of Leucaena, Australian Veterinary Journal, 63, 259-262

Lackey, J.A., 1977. A revised classification of the tribe Phaseoleae (Leguminosae: Papilionoideae), and its relation to canavanine distribution, Botanical Journal of the Linnean Society, 74, 163-178

Lima-Orozco, R. et al., 2014. Combined conservation of jack bean and velvet bean with sorghum: evaluation of lab-scale silages and in vitro assessment of their nutritive value, The Journal of Agricultural Science, 152, 967-980

Lima, R. et al., 2011. Digestibility, methane production and nitrogen balance in sheep fed ensiled or fresh mixtures of sorghum-soybean forage, Livestock Science, 141, 36-46

Makkar, H.P.S., Francis, G., and Becker, K., 2007a. Bioactivity of phytochemicals in some lesser-known plants and their effects and potential applications in livestock and aquaculture production systems, Animal, 1, 1371-1391

Makkar, H.P.S., Siddhuraju, P., and Becker, K., 2007b. Plant secondary metabolites, (Humana Press, Totowa, New Jersey, USA.) 
Mohamed, Z.Z., Sobhy, M.A.S., and Nader, D.S., 2018. Review article on Leucaena leucocephala as one of the miracle timber trees, International Journal of Pharmacy and Pharmaceutical Sciences, 10,

Moore, K.J., and Jung, H.-J.G., 2001. Lignin and fiber digestion, Rangeland Ecology \& Management/Journal of Range Management Archives, 54, 420-430

Nguyen, B.C.Q., and Tawata, S., 2016. The chemistry and biological activities of mimosine: A review, Phytotherapy Research, 30, 1230-1242

Njidda, A.A., and Nasiru, A., 2010. In vitro gas production and dry matter digestibility of tannin-containing forges of semi-arid region of North-Eastern Nigeria, Pakistan Journal of Nutrition, 9, 60-66

Rodgers, K.J., Samardzic, K., and Main, B.J., 2017. Toxic nonprotein amino acids. In: C.R. Carlini and R. Ligabue-Braun (eds), Plant Toxins, 2017, (Springer Netherlands, Dordrecht), 263-285

Rosenthal, G.A., 1991. Chapter 1 - Nonprotein amino acids as protective allelochemicals. In: G.A. Rosenthal and M.R. Berenbaum (eds), Herbivores: their Interactions with secondary plant metabolites (Second edition), 1991, (Academic Press, San Diego), 1-34

Schofield, P., 2000. Gas production methods. In: J.P.F. D'Mello (ed), Farm animal metabolism and nutrition, 2000, (CABI Publishing, Wallingford, Oxon OX10 8DE, UK), 209-232

Shelton, H.M., Kerven, G., and Dalzell, S.A., 2019. An update on leucaena toxicity: Is inoculation with Synergistes jonesii necessary?, Tropical Grasslands-Forrajes Tropicales, 7, 146-153

Siddhuraju, P., Vijayakumari, K., and Janardhanan, K., 1996. Chemical composition and protein quality of the little-known legume, velvet bean (Mucuna pruriens (L.) DC.), J Agric Food Chem, 44, 2636-2641

Soedarjo, M., and Borthakur, D., 1996. Simple procedures to remove mimosine from young leaves, pods and seeds of Leucaena leucocephala used as food, International Journal of Food Science \& Technology, $31,97-103$

Soltan, Y.A. et al., 2017. Potential of mimosine of Leucaena leucocephala for modulating ruminal nutrient degradability and methanogenesis, Animal Feed Science and Technology, 223, 30-41

Soltan, Y.A. et al., 2013. Contribution of condensed tannins and mimosine to the methane mitigation caused by feeding Leucaena leucocephala, Archives of Animal Nutrition, 67, 169-184

SPSS., 2012. Software for windows, release 21.0, Inc., 2012, Property of IBM Corporation. Chicago, Illinois. USA),

Udoh, P., and Ekpenyong, J., 2001. Effect of Mucuna urens (horse eye bean) on the gonads of male guinea-pigs, Phytotherapy Research, 15, 99-102 
Vaithiyanathan, S., Sheikh, Q., and Kumar, R., 2005. Effect of transinoculation of goat rumen liquor on degradation and metabolism of mimosine in sheep fed with Leucaena leucocephala leaves, AsianAustralas. j. anim. sci, 2005 v.18 no.3, pp. 332-339

Van Soest, P.J., Robertson, J.B., and Lewis, B.A., 1991. Methods for dietary fiber, neutral detergent fiber, and nonstarch polysaccharides in relation to animal nutrition, J Dairy Sci, 74, 3583-3597

Vlaeminck, B., Braeckman, T., and Fievez, V., 2014. Rumen metabolism of 22:6n-3 in vitro is dependent on its concentration and inoculum size, but less dependent on substrate carbohydrate composition, Lipids, $49,517-525$

Weimer, P.J., 2015. Redundancy, resilience, and host specificity of the ruminal microbiota: implications for engineering improved ruminal fermentations, Front Microbiol, 6,

\section{Tables}

Table 1. Contents (Means $\pm S D$ ) of organic matter (OM), crude protein (CP) and crude fiber (CF) as well as fiber fractions $(\mathrm{g} / \mathrm{kg} \mathrm{DM})$ and plant secondary metabolites of forage, bean and forage/bean (1:1) meals of three tropical legumes $(n=3)$. 


\begin{tabular}{llllll}
$\begin{array}{l}\text { Plant parts which meals } \\
\text { originate from }\end{array}$ & Forage & \multicolumn{2}{l}{ Forage/bean (1:1) meal } & Beans & \\
\hline Legumes & $\begin{array}{l}\text { L. } \\
\text { leucocephala }\end{array}$ & $\begin{array}{l}\text { C. } \\
\text { ensiformis }\end{array}$ & M. pruriens & $\begin{array}{l}\text { C. } \\
\text { ensiformis }\end{array}$ & M.pruriens \\
\hline OM & $939 \pm 1.0$ & $946 \pm 0.5$ & $937 \pm 0.2$ & $963 \pm 2.0$ & $945 \pm 2.0$ \\
\hline CP & $297 \pm 12.4$ & $237 \pm 10.7$ & $254 \pm 48.9$ & $320 \pm 1.4$ & $282 \pm 3.0$ \\
\hline CF & $259 \pm 1.7$ & $115 \pm 23.3$ & $119 \pm 1.7$ & $90 \pm 0.3$ & $70 \pm 0.0$ \\
\hline
\end{tabular}

Fiber fractions $^{\mathrm{a}}$

\begin{tabular}{lccccc}
\hline NDFom & $582 \pm 28.1$ & $302 \pm 61.1$ & $337 \pm 5.2$ & $365 \pm 0.7$ & $296 \pm 2.4$ \\
\hline ADFom & $347 \pm 16.4$ & $156 \pm 4.8$ & $194 \pm 17.9$ & $140 \pm 1.3$ & $113 \pm 2.3$ \\
\hline Hemicellulose & $235 \pm 44.5$ & $146 \pm 56.3$ & $144 \pm 23.0$ & $225 \pm 0.5$ & $183 \pm 0.1$ \\
\hline Cellulose & $242 \pm 11.4$ & $126 \pm 2.6$ & $161 \pm 14.9$ & $123 \pm 1.7$ & $94 \pm 1.7$ \\
\hline Lignin (pm) & $105 \pm 5.0$ & $30 \pm 2.2$ & $33 \pm 3.0$ & $17 \pm 0.1$ & $19 \pm 0.6$ \\
\hline Plant Secondary Metabolites $(\mathbf{g} / \mathbf{k g ~ D M}$ unless stated otherwise) & & & \\
\hline TI & $13.9 \pm 0.1$ & $13.9 \pm 0.1$ & $14.4 \pm 0.3$ & $22.1 \pm 0.4$ & $22.7 \pm 0.5$ \\
\hline L-canavanine & nd & $17.8 \pm 0.6$ & $19.1 \pm 0.0$ & $31.2 \pm 1.0$ & $33.4 \pm 0.1$ \\
\hline L-mimosine & $153 \pm 0.5$ & nd & nd & nd & nd \\
\hline Con A & nd & nd & nd & $8.4 \pm 0.5$ & nd \\
\hline
\end{tabular}

a NDFom: Neutral detergent fiber, ADFom: acid detergent fiber; ${ }^{b}$ nd: not determined; ${ }^{c}$ TI: trypsin inhibitor, Con A: Concanavalin A.

Table 2. ARDOM ( $\mathrm{g} / \mathrm{g} \mathrm{OM}$ ), total SCFA ( $\mathrm{mmol} / \mathrm{g} \mathrm{OM})$, and fermentation pattern of mixed bean-forage meals of $C$. ensiformis and $M$. pruriens and forage meal of $L$. leucocephala and degradation of the main plant secondary metabolites (ARDPSM; $\mathrm{g} / \mathrm{g}$ except for TI [TIU/TIU]) using rumen inoculum from Belgian sheep. 


\begin{tabular}{|c|c|c|c|c|c|}
\hline \multirow[t]{2}{*}{ Items } & \multicolumn{3}{|c|}{ Belgian sheep inoculum } & \multirow[t]{2}{*}{ SEM $^{2}$} & \multirow[t]{2}{*}{$P$-value } \\
\hline & C. ensiformis & M. pruriens & L. leucocephala & & \\
\hline ARDOM & $0.44^{\mathrm{a}}$ & $0.43^{\mathrm{a}}$ & $0.20^{\mathrm{b}}$ & 0.005 & $<0.001$ \\
\hline Total SCFA & $5.06^{\mathrm{a}}$ & $4.93^{\mathrm{a}}$ & $2.38^{\mathrm{b}}$ & 0.055 & $<0.001$ \\
\hline \multicolumn{6}{|c|}{ Fermentation pattern $\left(\mathrm{mmol} / \mathrm{mol} \mathrm{SCFA}_{t}\right)$} \\
\hline Acetate & $609^{b}$ & $601^{c}$ & $687^{a}$ & 2.5 & $<0.001$ \\
\hline Propionate & $251^{b}$ & $214^{c}$ & $260^{\mathrm{a}}$ & 1.4 & $<0.001$ \\
\hline Butyrate & $100^{b}$ & $127^{\mathrm{a}}$ & $36^{c}$ & 1.6 & $<0.001$ \\
\hline$|s o+V a|+C a p^{1}$ & $40^{\mathrm{b}}$ & $58^{\mathrm{a}}$ & $17^{\mathrm{c}}$ & 0.5 & $<0.001$ \\
\hline \multicolumn{6}{|l|}{ ARDPSM } \\
\hline Trypsin inhibitor & $0.98^{\mathrm{a}}$ & $0.98^{a}$ & $0.64^{\mathrm{b}}$ & 0.006 & $<0.001$ \\
\hline L-canavanine & 0.92 & 0.92 & - & 0.004 & 0.557 \\
\hline L-mimosine & - & - & 0.05 & - & - \\
\hline
\end{tabular}

Different superscripts in the same row $(a, b, c)$ indicate significant differences $(P<0.05)$ according to Tukey (1949). Abbreviations: ARDOM: apparent ruminal degradability of organic matter; SCFA: short chain fatty acids; ARDPSM: apparent ruminal degradability of plant secondary metabolites.

${ }^{1}$ Iso: isoacids (isobutyrate and isovalerate); Val: valerate; Cap: caproate.

2 SEM: Standard error of the mean

Table 3. ARDOM ( $\mathrm{g} / \mathrm{g} \mathrm{OM})$, total SCFA ( $\mathrm{mmol} / \mathrm{g} \mathrm{OM})$, and fermentation pattern of mixed bean-forage meals of $\mathrm{C}$. ensiformis and M. pruriens and forage meal of L. leucocephala and degradation of the main plant secondary metabolites (ARDPSM; $\mathrm{g} / \mathrm{g}$ except for TI [TIU/TIU]) using rumen inoculum from Cuban sheep. 


\begin{tabular}{|c|c|c|c|c|c|}
\hline \multirow[t]{2}{*}{ Items } & \multicolumn{3}{|c|}{ Cuban sheep inoculum } & \multirow[t]{2}{*}{ SEM $^{2}$} & \multirow[t]{2}{*}{$P$-value } \\
\hline & C. ensiformis & M. pruriens & L. leucocephala & & \\
\hline ARDOM & $0.50^{\mathrm{b}}$ & $0.59^{\mathrm{a}}$ & $0.35^{\mathrm{c}}$ & 0.012 & $<0.001$ \\
\hline Total SCFA & $6.29^{a}$ & $7.10^{\mathrm{a}}$ & $4.11^{\mathrm{b}}$ & 0.144 & $<0.001$ \\
\hline \multicolumn{6}{|c|}{ Molar proportions of SCFA $\left(\mathrm{mmol} / \mathrm{mol} \mathrm{SCFA}_{\mathrm{t}}\right)$ : } \\
\hline Acetate & $652^{\mathrm{b}}$ & $609^{c}$ & $682^{\mathrm{a}}$ & 2.6 & $<0.001$ \\
\hline Propionate & 200 & 196 & 173 & 6.7 & 0.175 \\
\hline Butyrate & $63^{b}$ & $112^{\mathrm{a}}$ & $96^{\mathrm{a}}$ & 3.0 & 0.001 \\
\hline $\mid s o+$ Val+Cap ${ }^{1}$ & $85^{a}$ & $83^{a}$ & $49^{b}$ & 1.6 & $<0.001$ \\
\hline \multicolumn{6}{|l|}{ ARDPSM } \\
\hline Trypsin inhibitor & $0.97^{b}$ & $0.97^{a}$ & $0.97^{b}$ & 0.000 & $<0.001$ \\
\hline L-canavanine & 0.98 & 0.96 & - & 0.008 & 0.481 \\
\hline L-mimosine & - & - & 0.78 & - & - \\
\hline
\end{tabular}

Different superscripts in the same row $(\mathrm{a}, \mathrm{b}, \mathrm{c})$ indicate significant differences $(P<0.05)$ according to Tukey (1949). Abbreviations: ARDOM: apparent ruminal degradability of organic matter; SCFA: short chain fatty acids; ARDPSM: apparent ruminal degradability of plant secondary metabolites.

${ }^{1}$ Iso: isoacids (isobutyrate and isovalerate); Val: valerate; Cap: caproate.

${ }^{2}$ SEM: Standard error of means

Table 4. Kinetic parameters of in vitro ruminal degradability of organic matter and plant secondary metabolites of bean meal from $C$. ensiformis and $M$. pruriens, and forage meal of $L$. leucocephala during a $24 \mathrm{~h}$ incubation period according to the model $A R D O M_{t}$ or ARDPSM $_{t}=$ Ass $/\{1+e x p[2-4 \times k f \times(t-L n)]\}$. 


\begin{tabular}{|c|c|c|c|c|c|}
\hline Legumes & & $\operatorname{Ln}(h)^{1}$ & $k f\left(h^{-1}\right)^{1}$ & Ass $(g / g)^{1}$ & $\mathrm{R}^{2}$ \\
\hline \multirow[t]{5}{*}{ Canavalia ensiformis } & ARDOM & $3.20^{c}$ & $0.05^{b}$ & $0.84^{y}$ & 0.987 \\
\hline & Trypsin inhibitor & $5.85^{\text {by }}$ & $0.42^{\text {a y }}$ & $0.79^{y}$ & 0.996 \\
\hline & L-canavanine & $11.79^{a}$ & $0.11^{b}$ & 0.91 & 0.995 \\
\hline & SEM $^{2}$ & 0.472 & 0.034 & 0.048 & \\
\hline & $P$-value & $<0.001$ & $<0.001$ & 0.114 & \\
\hline \multirow[t]{5}{*}{ Mucuna pruriens } & ARDOM & $1.92^{\mathrm{b}}$ & $0.05^{\mathrm{b}}$ & $0.75^{y}$ & 0.977 \\
\hline & Trypsin inhibitor & $5.48^{\text {a y }}$ & $0.37^{\text {a y }}$ & $0.72^{x y}$ & 0.996 \\
\hline & L-canavanine & $0.00^{\mathrm{b}}$ & $0.05^{\mathrm{b}}$ & 0.90 & 0.949 \\
\hline & SEM & 0.952 & 0.024 & 0.063 & \\
\hline & $P$-value & 0.003 & $<0.001$ & 0.062 & \\
\hline \multirow[t]{5}{*}{ Leucaena leucocephala } & ARDOM & 1.08 & 0.05 & $0.22^{b x}$ & 0.962 \\
\hline & Trypsin inhibitor & $-1.63^{x}$ & $0.09^{x}$ & $0.63^{a x}$ & 0.880 \\
\hline & L-mimosine & 1.21 & 1.46 & $0.05^{c}$ & 0.997 \\
\hline & SEM & 6.669 & 12.080 & 0.036 & \\
\hline & $P$-value & 0.893 & 0.991 & $<0.001$ & \\
\hline \multicolumn{6}{|c|}{ Statistics: comparison of ARDOM and ARDPSM kinetics between legumes } \\
\hline ARDOM & & 0.140 & 0.594 & $<0.001$ & \\
\hline Trypsin inhibitor & & $<0.001$ & $<0.001$ & 0.012 & \\
\hline L-canavanine & & $<0.001$ & 0.090 & 0.877 & \\
\hline
\end{tabular}

Different superscripts $\left({ }^{a}, b, c\right)$ in the same column and within each tropical legume indicate significant differences $(P<0.05)$ according to Tukey $(1949)$. 
Different superscripts $(x, y, z)$ in the same column indicate significant differences $(P<0.05)$ of ARDOM or trypsin inhibitor kinetic parameters between the tropical legume according to Tukey (1949).

${ }^{1} \mathrm{Ln}=$ lag time $(\mathrm{h}), \mathrm{kf}=\mathrm{ARDOM}$ and ARDPSM rate $\left(\mathrm{h}^{-1}\right)$ and Ass = asymptotic value, corresponding to the maximum degradation of OM and PSM (g/g except for TI [TIU/TIU]).

${ }^{2} \mathrm{SEM}=$ Standard error of means.

Abbreviations: ARDOM: apparent ruminal degradability of organic matter; ARDPSM: apparent ruminal degradability of plant secondary metabolites.

\title{
Figures
}
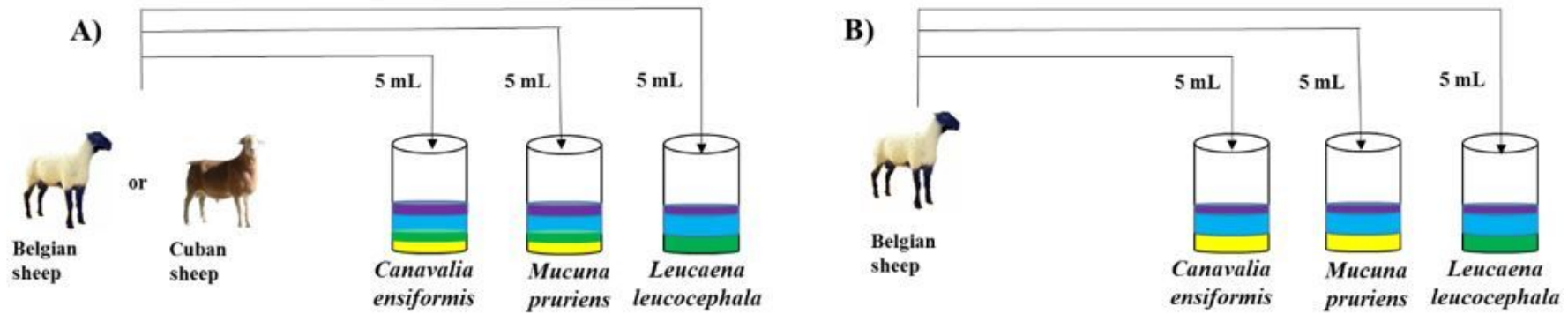

Experiment 1.1 and 1.2. Single-end point batch in vitro rumen incubation ( $24 \mathrm{~h})$

Experiment 2. In vitro rumen kinetic assessment $(0,2,4,6,8,10,12,24 \mathrm{~h})$

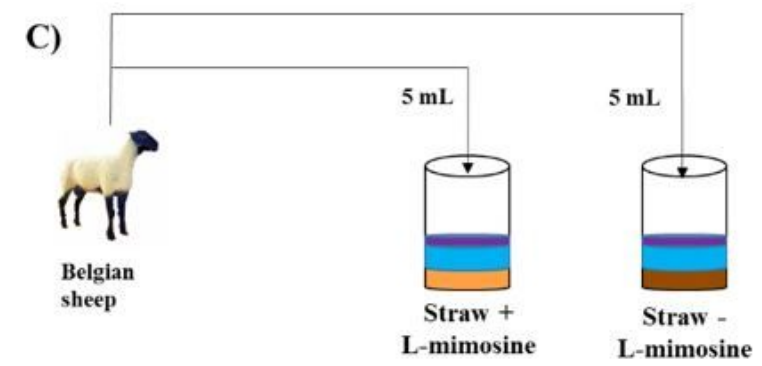

Experiment 3. In vitro rumen kinetic assessment $(0,2,6,10,24 \mathrm{~h})$

\begin{abstract}
Legend: or 1 : inoculum freshly obtained from Belgian or Cuban sheep, in the incubation flasks indicated in purple; Blue: Buffer; Green: forage meal of C. ensiformis, M. pruriens or L. leucocephala; Yellow: bean meal of C. ensiformis or M. pruriens ; Dark Brown: straw without L-mimosine; Light Brown: straw with Lmimosine.
\end{abstract}

\section{Figure 1}

Schematic representation of all in vitro ruminal incubations with the three tropical legumes. A) Experiment 1. In vitro assessment ( $24 \mathrm{~h}$ ) of apparent ruminal degradation of OM (ARDOM) and plant secondary metabolites (ARDPSM) of forage/bean (1:1) meal (C. ensiformis or M. pruriens) or forage 
meal of L. leucocephala using fresh inoculum from Belgian or Cuban sheep; B) Experiment 2. In vitro rumen kinetic assessment of ARDOM and ARDPSM of bean meal (C. ensiformis or M. pruriens) or forage meal of L. leucocephala using fresh inoculum from Belgian sheep; and C) Experiment 3. In vitro rumen kinetic assessment of ARDOM and ARDPSM of straw with or without L-mimosine using fresh inoculum from Belgian sheep.

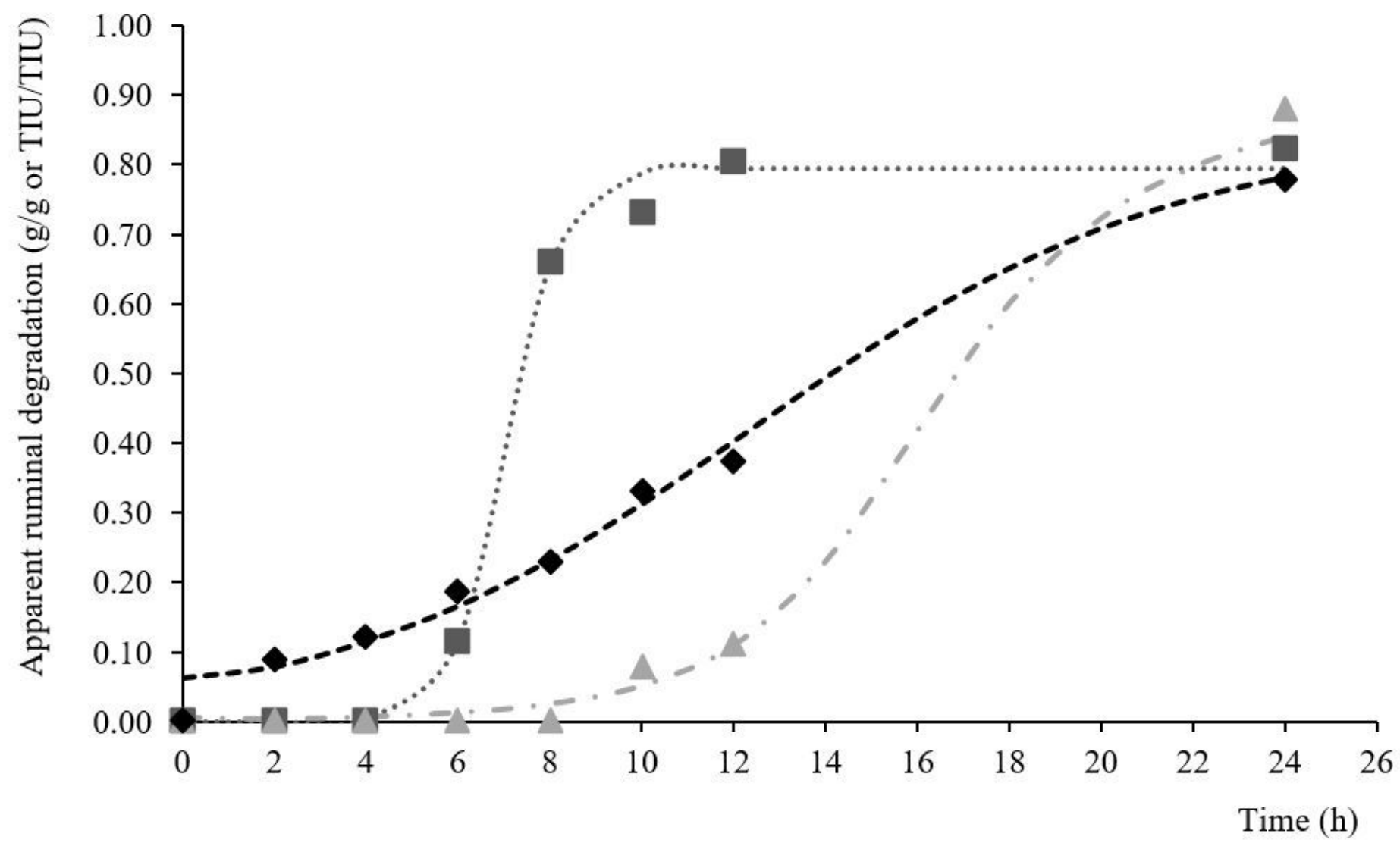
...... Model_Trypsin inhibitor - - - Model_L-canavanine
----Model_OM
$\triangle$ Data_L-canavanine

\section{Figure 2}

Kinetics of apparent ruminal degradability of organic matter and plant secondary metabolites of bean meal from Canavalia ensiformis. All degradabilities are expressed as $\mathrm{g} / \mathrm{g}$, except for trypsin inhibitor, expressed in TIU/TIU, with TIU = trypsin inhibitor units. 


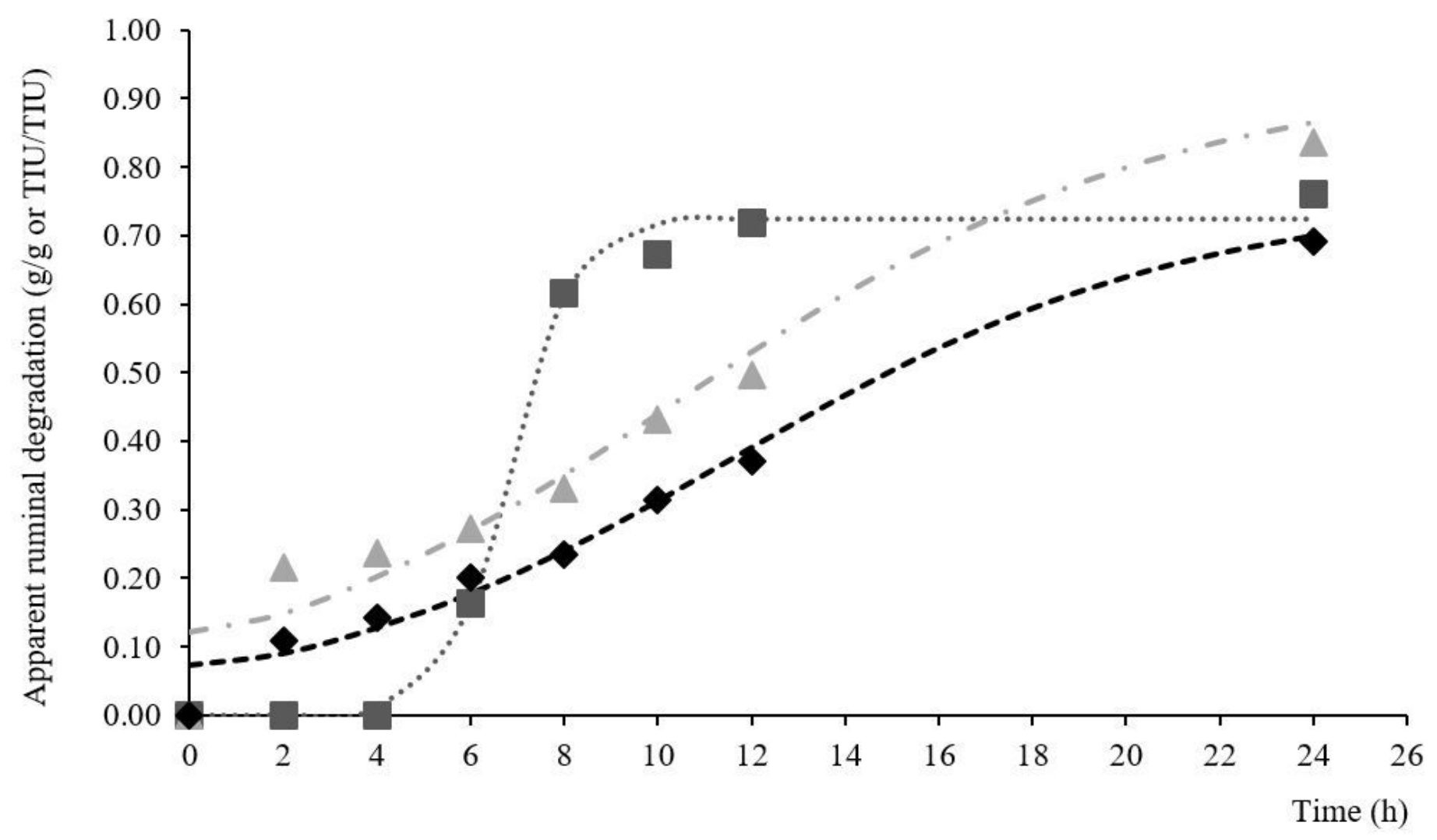

$\begin{array}{ll}\text { ….. Model_Trypsin inhibitor } & -\cdot-\text { Model_L-canavanine } \\ --- \text { Model_OM } & \text { Data_Trypsin inhibitor } \\ \Delta \quad \text { Data_L-canavanine } & - \text { Data_OM }\end{array}$

\section{Figure 3}

Kinetics of apparent ruminal degradability of organic matter and plant secondary metabolites of bean meal from Mucuna pruriens. All degradabilities are expressed as $\mathrm{g} / \mathrm{g}$, except for trypsin inhibitor, expressed in TIU/TIU, with TIU = trypsin inhibitor units. 


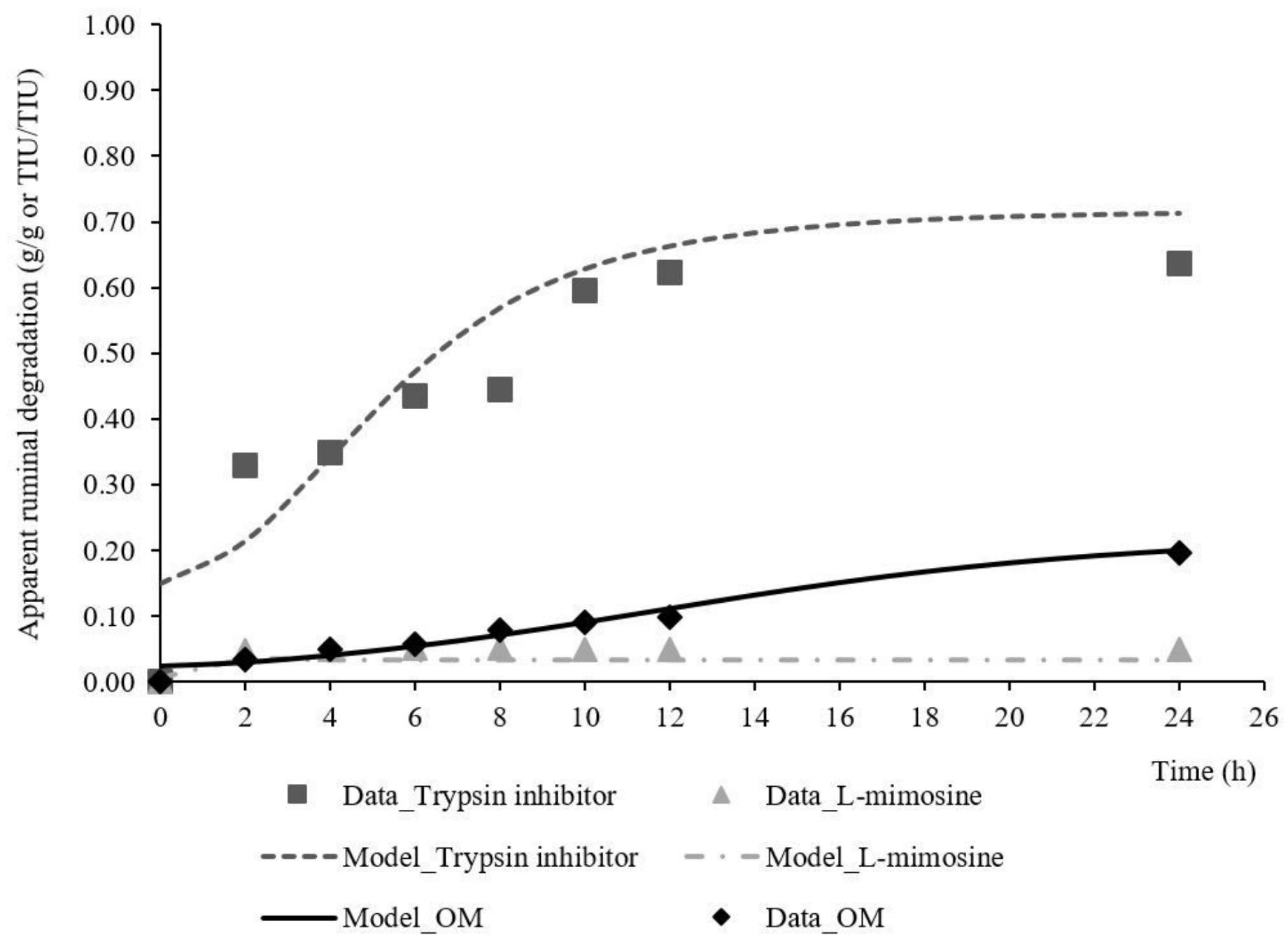

Figure 4

Kinetics of apparent ruminal degradability of organic matter and plant secondary metabolites of bean meal from Leucaena leucocephala. All degradabilities are expressed as $\mathrm{g} / \mathrm{g}$, except for trypsin inhibitor, expressed in TIU/TIU, with TIU = trypsin inhibitor units 


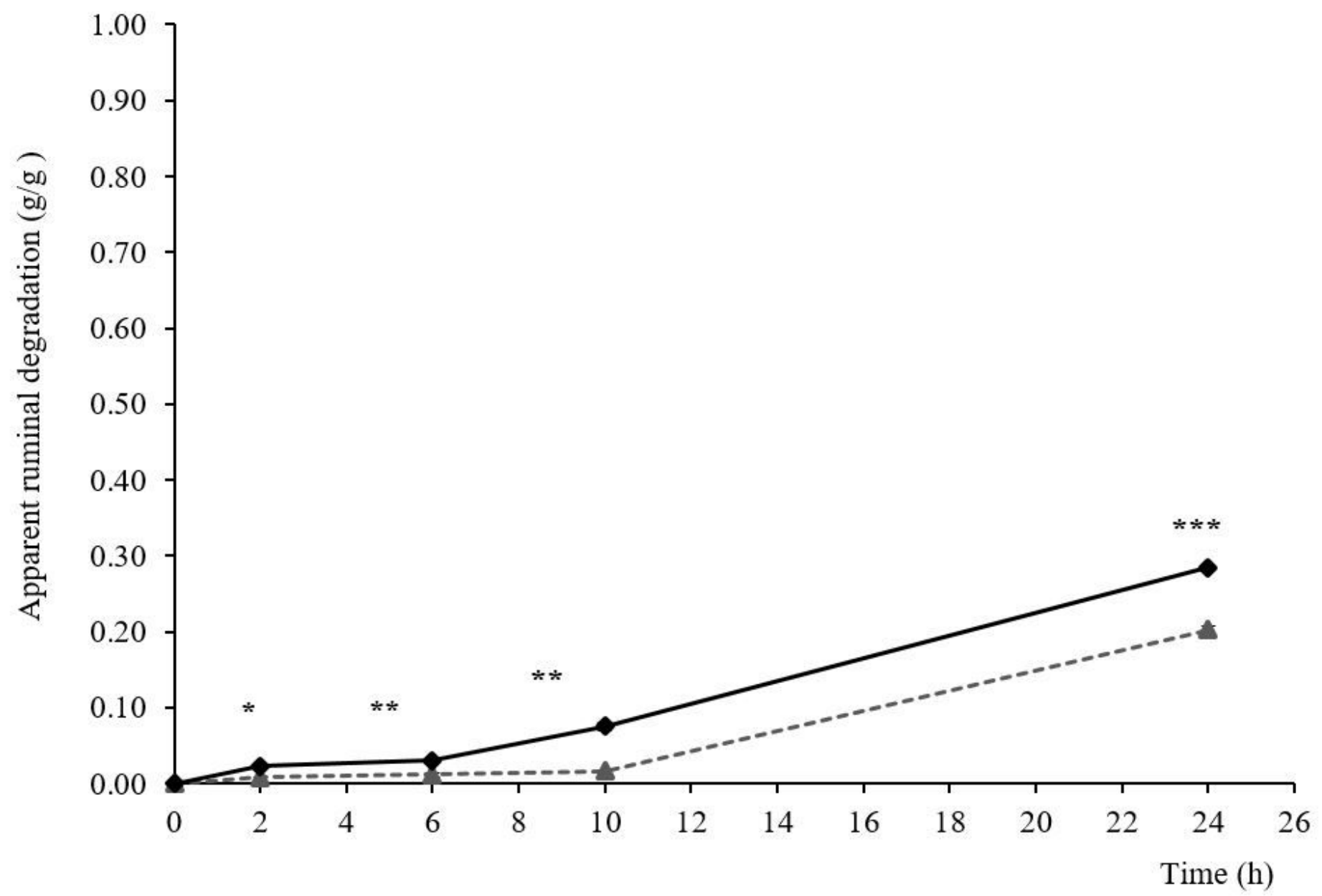

-- $\Delta--$ Straw+Mimosine $\longrightarrow$ Straw

Figure 5

Kinetics of apparent rumen degradability of organic matter (ARDOM) of straw with and without Lmimosine (One-way ANOVA test and Tukey's procedures for multiple comparison: *: $\mathrm{P}<0.05, \star \star$ : $\mathrm{P}<0.01$, $\star \star \star: P<0.001)$. 